\title{
China's Anti-Dumping Problems and Mitigation through Regional Trade Agreements
}

\author{
Yanlin Sun \\ John Whalley
}

CESIFO WORKING PAPER NO. 5227

CATEgory 8: Trade Policy

FEBRUARY 2015

An electronic version of the paper may be downloaded

- from the SSRN website:

- from the RePEc website:

- from the CESifo website:

WwW.SSRN.com

Www.RePEc.org

www.CESifo-group.org/wp 


\title{
China’s Anti-Dumping Problems and Mitigation through Regional Trade Agreements
}

\begin{abstract}
This paper highlights the severity of China's AD problems, and high concentration of $\mathrm{AD}$ actions taken by the top initiators, noting that China can offer a higher level of economic integration in an RTA in exchange for improved regional AD provisions. Case studies on RTAs give precedents in modifying regional AD provisions. Our finding of a weak effect of existing RTAs on mitigating China's AD problems suggests that China could become more active in mitigating AD problems by RTA negotiations.
\end{abstract}

JEL-Code: F130.

Keywords: anti-dumping, Regional Trade Agreement, mitigation.

Yanlin Sun

School of Economics

Wuhan University of Technology

Wuhan / Hubei / P.R. China

jocesunyl@126.com

\author{
John Whalley \\ Department of Economics \\ University of Western Ontario \\ Canada - N6A 5C2 London Ontario \\ jwhalley@uwo.ca
}

February 12, 2015

We are grateful to the ORF (Ontario Research Fund) and CIGI (Centre for International Governance Innovation) for financial support. 


\section{Introduction}

This paper explores opportunities for China's regional trade agreement initiatives to be used to mitigate the impacts of anti-dumping (hereinafter referred to as AD) actions. Over the past few decades, China has become the world's largest economy targeted by $\mathrm{AD}$ actions with associated high $\mathrm{AD}$ duties. In examining China's experience of frictions in the international trading system as it has transitioned to full WTO membership, Bown (2007) argued that there was no evidence that foreign actions against China via AD had declined since its accession to WTO. Many scholars believe that it is the current structure of multilateral rules on AD under the WTO that allows widespread use of AD protection. Prusa (2005) proposed that the Doha Round may be the last chance to significantly reform $\mathrm{AD}$ rules. However, since the current principle of Consensus in WTO makes it almost difficult to gain unanimity among the member states that have divergent interests, it seems that the effective way to improve AD disciplines may lie at regional level.

The current limited research on regional $\mathrm{AD}$ regimes focuses more on either the divergence of regional $\mathrm{AD}$ regimes from the multilateral rules on the basis of their legal text (see as Jean-Daniel Rey,2012), or on common characteristics of regional trade agreements (hereinafter referred to as RTAs) that could eliminate AD use within intra-RTA trade and their changing patterns of ADs (see as Robert The et al, 2007; Ryan Farha, 2013). Prusa (2011 and 2014) extend the scope of research on PTAs and discuss their AD usage trends, while Zimring (2014) uses a case study to analyze AD duty levels by US against non NAFTA countries with the implementation of NAFTA. 
Both find evidence that PTAs shift the burden of trade restraints onto non-members. However, existing research rarely deals with one country's initiative to modify AD regimes in its RTAs to improve the AD situation. Our motivation is to begin to fill this gap.

Our conclusions are as follows. Firstly, we note the high concentration of the share of $\mathrm{AD}$ actions taken by the top 4 and top $8 \mathrm{AD}$ initiators against China, which implies that China should take the initiative by establishing RTAs with its major AD initiators. Secondly, we note China's treatment as a non-market economy by some top $\mathrm{AD}$ initiators and the large export growth from China contribute to China's adverse AD situations. Importantly, one party can offer a higher level of economic integration or openness in exchange for an improvement in regional AD provisions. In addition, the exploration of modified AD provisions in some RTAs as precedents can shed light on China's possible future regional initiatives, and findings of a weak effect of regional $\mathrm{AD}$ provisions in mitigating $\mathrm{AD}$ actions against China by $\mathrm{RTA}$ members supports the position that China should make efforts to ameliorate its regional AD provisions. Finally, the paper suggests that China's RTAs bargaining strategy should aim at obtaining market economy status from intensive $\mathrm{AD}$ initiators, and also altering regional $\mathrm{AD}$ provisions. The paper offers initial thoughts on potential packages of concessions to be offered in exchange for amelioration in regional AD treatment.

The paper proceeds as follows. Section 2 describes China's AD problems. Section 3 explores reasons for the severity of AD actions against China. Section 4 examines the role of regional AD provisions in improving intra-RTA's AD situation. 
We also comment on varied regional $\mathrm{AD}$ arrangements in force as initiatives and China's current regional AD provisions. Section 5 explores prospects for China's bargaining strategy to improve regional AD arrangements. Section 6 concludes.

\section{The Severity of Anti-Dumping Actions against China}

This section sets out details of AD activities targeting China, focusing on the size, intensity, duty levels, and concentration of main AD initiators.

\section{a. Size}

In Table 1, we report the top 10 AD country targets, measured by the aggregated number of new initiations and measures during the period 1995-2013. China is the largest target economy for both $\mathrm{AD}$ initiations and $\mathrm{AD}$ measures. In terms of the share of the aggregate cases against China in the total cases worldwide, AD initiations against China contributed to $21.89 \%$ of total AD filings, while AD measures against China account for $24.78 \%$ of total measures during the period 1995-2013.

Table 1 Top 10 Economies targeted by aggregated number of AD initiations and AD measures during the period 1995-2013

\begin{tabular}{|l|l|r|r|l|l|r|}
\hline Rank & $\begin{array}{l}\text { Affected } \\
\text { Economies }\end{array}$ & $\begin{array}{l}\text { Aggregate } \\
\text { AD } \\
\text { Initiations }\end{array}$ & $\begin{array}{l}\text { Share of } \\
\text { aggregate } \\
\text { AD } \\
\text { initiations in } \\
\text { the world }\end{array}$ & $\begin{array}{l}\text { Affected } \\
\text { Economies }\end{array}$ & $\begin{array}{l}\text { Aggregate } \\
\text { AD } \\
\text { Measures }\end{array}$ & $\begin{array}{l}\text { Share of } \\
\text { aggregate } \\
\text { AD } \\
\text { measures in } \\
\text { the world }\end{array}$ \\
\hline 1 & China & 989 & $21.89 \%$ & China & 717 & $24.78 \%$ \\
\hline 2 & South Korea & 331 & $7.32 \%$ & South Korea & 199 & $6.88 \%$ \\
\hline 3 & United States & 255 & $5.64 \%$ & $\begin{array}{l}\text { Taipei, } \\
\text { Chinese }\end{array}$ & 162 & $5.60 \%$ \\
\hline 4 & Taipei, Chinese & 251 & $5.55 \%$ & United States & 150 & $5.18 \%$ \\
\hline 5 & Thailand & 188 & $4.16 \%$ & Japan & 126 & $4.35 \%$ \\
\hline 6 & Japan & 180 & $3.98 \%$ & Thailand & 121 & $4.18 \%$ \\
\hline 7 & India & 177 & $3.92 \%$ & Indonesia & 110 & $3.80 \%$ \\
\hline 8 & Indonesia & 177 & $3.92 \%$ & Russia & 105 & $3.63 \%$ \\
\hline 9 & Russian & 132 & $2.92 \%$ & India & 103 & $3.56 \%$ \\
\hline 10 & Federation & 123 & $2.72 \%$ & Brazil & 86 & $2.97 \%$ \\
\hline
\end{tabular}


Source: WTO's Statistics on Anti-dumping

\section{b. AD intensity}

China accounts for $11.16 \%$ and $10.32 \%$ of global exports and imports in 2013 . Because of China's large and growing share of international trade and the growing size of its economy, it is perhaps not surprising to see it being named frequently in AD filings.

A first measure of $\mathrm{AD}$ intensity is "AD-export ratio", which is defined as an economy's share of AD cases in the world divided by its share of world exports. If an economy's $\mathrm{AD}$-export ratio is above 1 , it means that the economy is being targeted more than its share in exports (Chu \& Prusa, 2004). Table 2 reports comparisons of "AD export" ratios in the top $10 \mathrm{AD}$ targeted economies. During the period 1995-2013, China ranks $5^{\text {th }}$ with a value of 2.71 , a level much higher than that in the other 3 of top 4 large export economies with values less than 0.72 (including the U.S., Germany $^{2}$ and Japan). Such high 'AD export' ratio means that China is being named somewhat more intensively than other large export economies given its trade value, but this is less than some other developing countries (such as Indonesia ,Thailand and India).

\footnotetext{
${ }^{2}$ In our calculation on the basis of WTO AD database, German is the $12^{\text {th }}$ target economy of AD investigation cases. During the period 1995-2013, the share of aggregated AD initiations in the world is $2.26 \%$, the aggregate world export share is $8.93 \%$, and the AD export intensity is 0.25 . 
Table 2 "AD export" ratio in the top 10 targeted economies during 1995-2013

\begin{tabular}{|l|l|r|r|r|}
\hline Rank & Affected Economies & $\begin{array}{l}\text { Aggregate AD } \\
\text { initiations share }\end{array}$ & $\begin{array}{l}\text { Aggregate } \\
\text { Export share }\end{array}$ & AD -export ratio \\
\hline 1 & China & $21.89 \%$ & $8.08 \%$ & 2.71 \\
\hline 2 & South Korea & $7.32 \%$ & $2.80 \%$ & 2.61 \\
\hline 3 & United States & $5.64 \%$ & $9.24 \%$ & 0.61 \\
\hline 4 & Taipei, Chinese & $5.55 \%$ & $1.81 \%$ & 3.06 \\
\hline 5 & Thailand & $4.16 \%$ & $1.14 \%$ & 3.66 \\
\hline 6 & Japan & $3.98 \%$ & $5.50 \%$ & 0.72 \\
\hline 7 & India & $3.92 \%$ & $1.17 \%$ & 3.35 \\
\hline 7 & Indonesia & $3.92 \%$ & $0.90 \%$ & 4.36 \\
\hline 9 & Russian Federation & $2.92 \%$ & $2.30 \%$ & 1.27 \\
\hline 10 & Brazil & $2.72 \%$ & $1.16 \%$ & 2.35 \\
\hline
\end{tabular}

Source: Calculations based on WTO's Statistics on Anti-dumping and International Trade Indicators in UNCTAD statistics

Table 3 reports on another dimension of $\mathrm{AD}$ intensity in the top 10 targeted economies in terms of affirmative ratios, defined as the number of measures divided by the number of initiations targeting a particular economy. During 1995-2013, 72.5\% of all $\mathrm{AD}$ initiations against China received an affirmative final determination, which makes China the second highest affirmative ratio among the top $10 \mathrm{AD}$ targeted economies.

Table 3 Affirmative ratio in the top $10 \mathrm{AD}$ targeted economies during 1995-2013

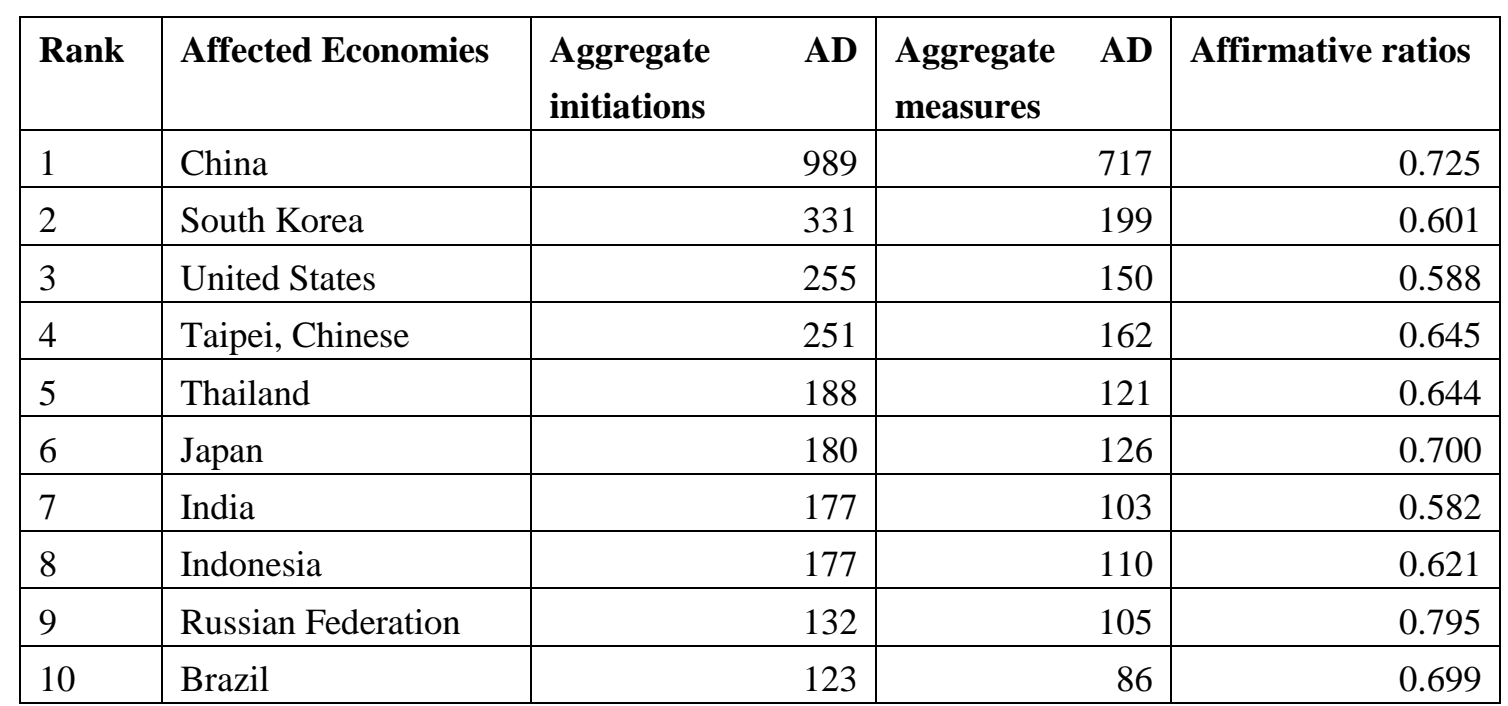

Source: Calculations based on WTO's Statistics on Anti-dumping 


\section{AD duty (ADD) level}

We also consider AD duties (ADD) imposed by the top 12 initiators of AD against China. Taking the U.S. as an example, the average ADD during the period 1980-2013 amounted to $134.46 \%$, the average ADD during the period 1995-2013 amounted to $145.77 \%$, the average ADD during the period $2003-2013$ is $153.08 \%$. Compared with an average ADD of $54 \%$ imposed by US on Chinese export during period 1995-2002, it can be concluded that the duties imposed by the U.S. tend to be even much higher than before. We report comparisons of ADD in the top 12 initiators of AD against China during the period 1995-2013 in Table 4. The table shows that the top 5 countries with the highest average ADD on China are Argentina, Colombia, the U.S., Mexico and India.

Table 4 ADDs in the Top 12 initiators of AD against China during the period 1995-2013

\begin{tabular}{|c|c|c|c|c|c|}
\hline $\begin{array}{l}\text { Top } 12 \\
\text { Initiators }\end{array}$ & $\begin{array}{l}\text { Aggregate AD } \\
\text { initiations } \\
\text { against China (1) }\end{array}$ & $\begin{array}{l}\text { Average } \\
\text { ADD } \\
\text { against } \\
\text { China(2) }\end{array}$ & $\begin{array}{l}\text { Rank of } \\
\text { Average ADD } \\
\text { against } \\
\text { China(3) }\end{array}$ & $\begin{array}{l}\text { Average ADD } \\
\text { against world } \\
\text { economy(4) }\end{array}$ & $(2) /(4)$ \\
\hline India & 161 & $126.52 \%$ & 5 & $89.46 \%$ & 1.41 \\
\hline U.S. & 117 & $153.08 \%$ & 3 & $79.00 \%$ & 1.94 \\
\hline $\mathrm{EU}$ & 114 & $42.41 \%$ & 11 & $30.76 \%$ & 1.38 \\
\hline Argentina & 90 & $246.21 \%$ & 1 & $121.31 \%$ & 2.03 \\
\hline Brazil & 78 & $80.85 \%$ & 8 & $42.88 \%$ & 1.89 \\
\hline Turkey & 64 & $57.05 \%$ & 9 & $35.33 \%$ & 1.61 \\
\hline Australia & 41 & $48.07 \%$ & 10 & $38.09 \%$ & 1.26 \\
\hline Mexico & 40 & $134.04 \%$ & 4 & $63.45 \%$ & 2.11 \\
\hline $\begin{array}{l}\text { South } \\
\text { African }\end{array}$ & 38 & $54.44 \%$ & 8 & $47.22 \%$ & 1.15 \\
\hline Colombia & 36 & $186.55 \%$ & 2 & $192.72 \%$ & 0.97 \\
\hline Canada & 34 & $83.48 \%$ & 7 & $62.44 \%$ & 1.34 \\
\hline $\begin{array}{l}\text { South } \\
\text { Korea }\end{array}$ & 25 & $23.09 \%$ & 12 & $23.58 \%$ & 0.98 \\
\hline
\end{tabular}

Source: The data of AD initiations against China is from WTO's Statistics on anti-dumping; Data on ADD is from Bown, Chad P. (2014) "Global Antidumping Database," The World Bank, June, available 
In the $5^{\text {th }}$ column of Table 4 , we divide the ADDs against China by those imposed by each of the top 12 initiators against world. It can be inferred that compared with their average ADD level across the world, 10 out of top 12 AD initiators took discriminatory $\mathrm{AD}$ actions against China. The most severe discrimination treatments against China originate from Mexico, and then followed by Argentina and the U.S. On the contrary, South Korea and Colombia treat China less harshly compared with other economies.

\section{d. Concentration of $\mathrm{AD}$ cases against China in terms of $\mathrm{AD}$ initiators}

During the period 1995-2013, there are a total of 32 countries that have initiated $\mathrm{AD}$ investigation actions and taken $\mathrm{AD}$ measures against China. We calculate the concentration level of $\mathrm{AD}$ cases initiated by China's and world's initiators. The concentration ratios of $\mathrm{AD}$ cases are defined as the share of aggregate $\mathrm{AD}$ cases initiated by the top 4 or top 8 investigators. As shown in Table 5, there are higher concentration levels in the $\mathrm{AD}$ initiations and $\mathrm{AD}$ measures against China than $\mathrm{AD}$ initiations worldwide.

Table 5 Concentration ratios of AD cases initiated by China's initiators and world's main initiators during the period 1995-2013

\begin{tabular}{|c|c|c|c|c|}
\hline \multirow[t]{2}{*}{ type of initiators } & \multicolumn{2}{|c|}{ Concentration ratios of $\mathrm{AD}$ initiations } & \multicolumn{2}{|c|}{$\begin{array}{l}\text { Concentration ratios of } \mathrm{AD} \\
\text { measures }\end{array}$} \\
\hline & $\begin{array}{l}\text { Share of aggregate } \\
\text { cases Against } \\
\text { China }\end{array}$ & $\begin{array}{l}\text { Share of } \\
\text { aggregate cases } \\
\text { Worldwide }\end{array}$ & $\begin{array}{l}\text { Share of } \\
\text { aggregate cases } \\
\text { Against China }\end{array}$ & $\begin{array}{l}\text { Share of } \\
\text { aggregate cases } \\
\text { Worldwide }\end{array}$ \\
\hline top 4 initiators & $48.7 \%$ & $44.2 \%$ & $52.3 \%$ & $46.7 \%$ \\
\hline top 8 initiators & $71.2 \%$ & $66.7 \%$ & $72.6 \%$ & $68.0 \%$ \\
\hline
\end{tabular}

Source: Calculations based on WTO's Statistics on Anti-dumping 


\section{Reasons for the Severity of China's Anti-Dumping Problems}

The AD, as one of the few WTO-consistent instruments of protection, has become increasingly important in addressing global trade issues. This is in part also due to its considerable discretion and vagueness surrounding the determination of dumping margins, injury and causal link encoded in AD provisions in WTO agreements (Blonigen and Prusa 2001).

On studying the AD files against China during 1995-2001, Chu and Prusa (2004) proposed some likely contributing factors including non-market economy status, easily above low threshold for cumulation resulting from large exports, the strategic use of $\mathrm{AD}$, weakness in corporate governance, the significant amount of Chinese FDI coming from four East-Asian Tigers and a low concentration ratio in Chinese industries. Since Prusa's study is based on data before 2002, some changes have taken place in China's economy, such as improvements in Chinese enterprises' corporate governance and their growing experience in taking effective legal defense against AD actions. Also the industry concentration level in the AD susceptible sectors like chemicals and base metals has increased.

Chinese scholars have also made some insightful research on this area. Xiaohua Bao (2011) argued that there exist considerable discretion and discrimination in AD measures against China taken by both developing countries and developed countries. In all, there is widely accepted opinion among Chinese scholars that huge export growth and export surplus, China's non-market economy status, and also the low-price strategy of China's exporters contribute to a high incidence of AD cases against China with high AD duties. 


\section{a. Non-Market Economy Status （NME）}

Where economies have non-market economy status, the WTO AD rules allow an investigating economy not to use the exporter's domestic prices in the determination of dumping, because a strict comparison with home market prices may not be appropriate. Importing countries have thus exercised significant discretion, by using the domestic price of other countries, in the calculation of normal value of products exported from non-market economies. Being classified as a non-market economy makes it difficult for exporting countries to defend themselves.

According to the accession protocol of China to WTO, China agreed to be treated as a non-market economy for another 15 years (which means that will expire in 2016). Because China is classified as non-market economy, investigators can assert that Chinese domestic prices fail to reflect the true cost of inputs as determined in the markets. Therefore, investigating countries need not recognize China's major comparative advantage in international trade resulting from the low labor cost, and can use the domestic input prices in other countries in determining the production cost of Chinese goods. Such practices greatly increase China's risk in dumping allegations.

Among 32 economies that have taken AD measures against China, there are now 22 countries that have already accorded market economy status to China. However, none of the top three AD initiators against China (India, US and EU) has acknowledged China's market economy status, and only 3 out of top $8 \mathrm{AD}$ initiators have accorded market economy status to China. 
Table 6 Comparison of AD measures against China by two country groups during the period 1995-2013

\begin{tabular}{|l|r|r|r|}
\hline \multicolumn{1}{|c|}{ Group } & \multicolumn{1}{c|}{$\begin{array}{c}\text { Number of } \\
\text { countries }\end{array}$} & $\begin{array}{c}\text { Aggregate AD } \\
\text { measures }\end{array}$ & $\begin{array}{c}\text { Average of AD measures } \\
\text { by country }\end{array}$ \\
\hline $\begin{array}{l}\text { Group 1 not acknowledging market } \\
\text { economy status }\end{array}$ & 10 & 440 & 44 \\
\hline $\begin{array}{l}\text { Group2 acknowledging market } \\
\text { economy status }\end{array}$ & 22 & 277 & 12.59 \\
\hline
\end{tabular}

Source: The data on AD measures is from WTO's Statistics on Anti-dumping; Classification of groups with different views on China's market economy status on the basis of various official news and documents released by Ministry of Commerce of the people's republic of China

In Table 6, we divide 32 countries into 2 groups. The higher average value of AD measures in group 1 partially implies that the group not having yet acknowledged China's market economy status tends to take more AD measures than the group of countries that have already granted this status to China. Thus, NME status contributes to adverse $\mathrm{AD}$ treatment on China's exports. In Table 4, among the top 5 countries with the highest average ADD, only Argentina has accorded market economy status to China, which equally suggests that NME status leads to high ADD levels against China.

\section{b. Large Export Growth from China}

Table 7 shows that, since China's accession to WTO in 2001, China's export share has increased considerably in the import markets of top $12 \mathrm{AD}$ initiators. During the period 2002-2013, aggregate imports from China rank among the top 3 in the top 12 AD initiators' import markets, the only exception being Argentina. The surge of China's exports in foreign markets, has had detrimental effects on foreign country's trade balance account, as a result, they will resort to AD to offset such detrimental effects. For example, Chow (2014) argues that AD stems from the growth of the 
expanding U.S. trade deficit with China; Chang Hwan Choia \& Jae-Woo Kima （2014） find that most of India's AD measures primarily target Chinese products due to the trade deficit caused by large growth in imports from China.

Moreover, in article 3 of determination of injury, WTO AD rules allow the investigating authorities to cumulatively assess the effects of such imports where imports of a product from more than one country are simultaneously subject to AD investigations. The volume of dumped imports shall be regarded as significant under one of two conditions. One is that the volume of dumped imports from a country is found to account for no less than 3 percent of imports of the like product in the importing Member. And the alternative condition is that countries which individually account for less than 3 percent of the imports of the like product in the importing member collectively account for more than 7 per cent of imports of the like product in the importing Member. Therefore under WTO AD rules, China's import market share in a particular economy can easily exceed to the low threshold (Chu and Prusa 2004), which likely leaded to high incidence of $\mathrm{AD}$ actions against China.

Table 7 Rank of imports from China in the AD initiators economies

\begin{tabular}{|l|l|lr|lr|l|l|}
\hline Rank & $\begin{array}{l}\text { AD } \\
\text { initiators }\end{array}$ & \begin{tabular}{l} 
Share \\
China in its \\
total import in \\
\cline { 4 - 7 }
\end{tabular} & $\mathbf{2 0 1 3}$ & $\begin{array}{l}\text { Rank of import from China in AD initiators } \\
\text { Imports in }\end{array}$ & $\begin{array}{l}\text { Imports in } \\
\mathbf{2 0 1 3}\end{array}$ & $\begin{array}{l}\text { Aggregate imports } \\
\text { during 2002-2013 }\end{array}$ \\
\hline 1 & India & $11.4 \%$ & 5 & 1 & 2 \\
\hline 2 & U.S. & $19.8 \%$ & 5 & 1 & 2 \\
\hline 3 & EU & $16.6 \%$ & 3 & 1 & 1 \\
\hline 4 & Brazil & $15.6 \%$ & 7 & 2 & 3 \\
\hline 5 & Argentina & $15.4 \%$ & 4 & 3 & 4 \\
\hline 6 & Australia & $19.3 \%$ & 4 & 1 & 2 \\
\hline
\end{tabular}




\begin{tabular}{|l|l|r|r|r|r|}
\hline 7 & $\begin{array}{l}\text { South } \\
\text { African }\end{array}$ & $15.3 \%$ & 6 & 2 & 2 \\
\hline 8 & Mexico & $16.09 \%$ & 5 & 2 & 2 \\
\hline 9 & Turkey & $9.81 \%$ & 7 & 3 & 3 \\
\hline 10 & Colombia & $17.5 \%$ & 3 & 1 & 1 \\
\hline 11 & Canada & $11.1 \%$ & 4 & 3 & 3 \\
\hline 12 & South Korea & $16.1 \%$ & 4 & 1 & 1 \\
\hline
\end{tabular}

Source: Calculations based on International Trade Indicators in UNCTAD statistics

\section{The Use of Existing Regional Initiatives to Mitigate Anti-dumping Problems as a Precedent for China's RTA Negotiation}

\section{a. The Role of RTA in Mitigating AD Problem}

As one of the few WTO-consistent instruments of protection, AD is part of "safeguards" without which tariff liberalization could not occur. Mastel (1998) argued that dumping is driven by closed home markets. Theoretically, the primary economic objective of RTAs is to eliminate barriers to intra-regional trade between members, and thus AD would finally be removed with deepening integration of RTAs. Hoekman (1998) argued that the impetus to eliminate AD remedies within RTAs is the broader push for economic integration and, relatedly, the desire to "extract concessions" from other parties to the agreement. Equally, Prusa (2014) argues that when countries can earn supernormal profits from the formation of RTAs, the barriers for intra-RTA trade will be eliminated for they no longer need to protect their home markets, and the AD use will be limited or even prohibited. Current research, focusing on the common characteristics of RTAs eliminating the AD use within intra-RTA trade (see Robert The et al, 2007; Jean-Daniel Rey, 2012; Ryan Farha, 2013), also argues that the leading candidate to explain the abolition of $\mathrm{AD}$ is the depth of market integration envisioned in the RTA. 
Though little research exists on the common characteristics of RTAs that restrict the use of $\mathrm{AD}$, in discussing the bargaining strategy of NAFTA in which introduction of binational review is stipulated in the regional AD regime, Whalley (1996) pointed out that some degree of exemption from the use of AD sought by Canada were secured by implicit side payments in the form of domestic policy disciplines favorable to United States. Such side payments can be considered as the price which makes USA willing to make some concession in the use of AD protection as a pay back. Consequently, during RTAs' negotiation, one party can offer a bid with a high level of economic integration and economic openness in exchange for an improvement in regional $\mathrm{AD}$ arrangements.

Not only can it be paid by provisions which eliminate or restrict the use of AD within RTAs, the supernormal profit benefiting from the integration or openness can even sometimes devalue the role of AD. For example, when deeper integration lies in the harmonization of institution and policies, the value of $\mathrm{AD}$ in protecting unfair trade resulting from the differences in competition conditions and international segmentation of markets will decrease.

\section{b Overall distribution of AD provisions in current RTAs}

On the basis of classification criteria developed by Jean-Daniel Rey (2012) in his WTO working report, three varieties of regional AD regimes in RTAs can be developed. In category A, RTAs simply confirm or make reference to rights and obligations in WTO's agreement on AD. The category B explicitly eliminates the use of $\mathrm{AD}$ measures against intra-RTA exports, and Category $\mathrm{C}$ contains specific 
restrictive provisions which limit the use of AD against RTA's partners.

Table 8 Categories of regional AD provisions

\begin{tabular}{|c|c|c|c|c|c|c|}
\hline \multirow[t]{2}{*}{ Category } & \multicolumn{2}{|c|}{ Total by $10 / 2014$} & \multicolumn{2}{|c|}{$\begin{array}{l}\text { RTAs notified to WTO by } \\
10 / 2010 \text { (Rey, 2012) }{ }^{3}\end{array}$} & \multicolumn{2}{|c|}{$\begin{array}{l}\text { RTAs notified to WTO } \\
\text { between } 10 / 2010 \text { and } \\
10 / 2014\end{array}$} \\
\hline & numbers & share & Numbers & share & Numbers & share \\
\hline Category A & 210 & $83.00 \%$ & 173 & $90.10 \%$ & & $60.66 \%$ \\
\hline Category B & 19 & $7.51 \%$ & 14 & $7.29 \%$ & & $8.20 \%$ \\
\hline Category C & 24 & $9.49 \%$ & 5 & $2.60 \%$ & & $31.15 \%$ \\
\hline Total & 253 & $100 \%$ & 192 & $100 \%$ & & $100 \%$ \\
\hline
\end{tabular}

Source: Classification and Calculation based on WTO staff working report (Jean-Daniel Rey, 2012), and documents of RTAs listed in WTO's RTA database

By comparing 253 RTAs' data notified to the WTO by 10/2014 with data ending in $10 / 2010$ in the WTO working paper by Jean-Daniel Rey (2012), Table 8 demonstrates some characteristics of the regional AD regimes favored by RTAs.

Firstly, $83 \%$ of RTAs simply confirm WTO's AD provisions, though the share tends to decline in recent three years. Secondly, Only 19 RTAs $(7.51 \%)$ prohibit intra-regional AD measures. Since 2010, all of the 5 RTAs eliminating the intra-regional AD measures are concluded between EFTA and other countries. Such low proportions can be accounted for by the arguments that the possibility of eliminating the $\mathrm{AD}$ measure exists in RTAs which envision deeper integration and in

\footnotetext{
${ }^{3}$ Note that the result of categorization of regional AD provisions in RTAs notified to WTO by 10/2010 comes from WTO staff working report (Jean-Daniel Rey, 2012). In the report, Rey classifies RTAs into two categories. In category A, regional AD provisions simply confirm WTO's AD provisions. In category $\mathrm{B}$, there are two sub-categories: $\mathrm{Ba}$ and $\mathrm{Bb}$. In sub-category $\mathrm{Ba}, \mathrm{RTAs}$ prohibit the use of $\mathrm{AD}$ at intra-regional level; while in $\mathrm{Bb}$, RTAs restrict the rights of RTA Parties to take AD measures. Because we focuses more on RTAs that constrain the rights of AD use, category B in our paper corresponds to category Ba in report by Jean-Daniel Rey (2012), and category C corresponds to category Bb in report by Jean-Daniel Rey(2012). Moreover, in report by Jean-Daniel Rey (2012), the regional AD regime of NAFTA was listed in category A, and we list NAFTA in category C, because the creation of binational panel in chapter 19 is considered as one alteration in AD rules (as in Prusa (2014).)
} 
which partners have rarely used AD measures against each other (Ryan Farha, 2007). This suggests a low possibility for China to achieve the prohibition of AD within intra-RTA trade.

More importantly, Table 8 shows a difference from the periods before 10/2011, in that the share of the number of RTAs restricting regional AD provisions has increased considerably from its former level of $2.60 \%$ to $31.15 \%$. The total number amounts to 19 between 10/2010 and 10/2014 reflecting the prospect of mitigating AD problems. In addition, accompanied by the increasing use of category $\mathrm{C}$ recently, some new elements of revision are found in the newly notified RTAs' AD provisions.

With regards to stricter conditions to trigger the use of $\mathrm{AD}$, the new RTAs have frequently introduced the less duty rule as mandatory rule to reduce the level of AD duty instead of setting up higher de minimis levels or a making sunset to shorter duration for the measures. Also the prohibition of zero is specified in some new RTAs to reduce the likelihood of the initiation of AD investigation. As far as modifications in procedure are concerned, none of them have established binational review commissions as in CUFTA and NAFTA. New initiatives, including the establishment of joint committee and working groups, and defining the time period for consultation or notification, aim to improve transparency and cooperation between RTAs' partners. All of these elements reduce the administration discretion and make it more difficult to initiate or take $\mathrm{AD}$ measures. Therefore, it is believed that Category $\mathrm{C}$ will be one feasible way for a country to mitigate its AD problems.

\section{c. Case studies as precedents for China's FTAs and AD}

To further discuss the role of economic integration in altering regional AD 
regimes and also the effects of such alterations, we report on case studies of the EU, US and India, the top 3 AD initiators against China.

Table 9 Initiatives of regional AD regimes in some RTAs of EU, US and India

\begin{tabular}{|c|c|c|c|c|c|c|}
\hline \multicolumn{7}{|c|}{ EU's RTAs notified to WTO after 10/2011 } \\
\hline \multicolumn{2}{|c|}{ partners } & $\begin{array}{l}\text { Type or } \\
\text { regional } \\
\mathrm{AD} \\
\text { regimes }\end{array}$ & Type of RTAs & $\begin{array}{ll}\text { Aggregate } & \mathrm{AD} \\
\text { initiations by } & \mathrm{EU} \\
\text { against partner } & \\
(1995-2013) & \end{array}$ & $\begin{array}{l}\text { Year of } \\
\text { entry } \\
\text { into } \\
\text { force }\end{array}$ & $\begin{array}{l}\text { Aggregate } \mathrm{AD} \\
\text { initiations by } \\
\mathrm{EU} \text { against } \\
\text { partner after the } \\
\text { entry into force }\end{array}$ \\
\hline \multicolumn{2}{|l|}{$\begin{array}{l}\text { Central } \\
\text { American }\end{array}$} & A & FTA $^{4} \&$ EIA & 1 & 2012 & 0 \\
\hline \multicolumn{2}{|c|}{$\begin{array}{l}\text { Colombia and } \\
\text { Peru }\end{array}$} & A & FTA \&EIA & 0 & 2012 & 0 \\
\hline \multicolumn{2}{|c|}{ EPA } & A & FTA \&EIA & 0 & 2009 & 0 \\
\hline \multicolumn{2}{|l|}{ Georgia } & $\mathrm{A}$ & FTA \&EIA & 0 & 2014 & 0 \\
\hline \multicolumn{2}{|c|}{ South Korea } & $\mathrm{C}$ & FTA \&EIA & 28 & 2010 & 0 \\
\hline \multicolumn{2}{|c|}{$\begin{array}{l}\text { Papua New } \\
\text { Guinea / Fiji }\end{array}$} & $\mathrm{A}$ & FTA \&EIA & 0 & 2009 & 0 \\
\hline \multicolumn{2}{|c|}{ Moldova } & $\mathrm{C}$ & FTA \&EIA & 1 & 2014 & 0 \\
\hline \multicolumn{2}{|l|}{ Ukraine } & $\mathrm{C}$ & FTA \&EIA & 14 & 2014 & 0 \\
\hline \multicolumn{7}{|c|}{ Examples of US's RTAs } \\
\hline partners & \multicolumn{2}{|c|}{\begin{tabular}{|l|} 
Type of \\
regional \\
$\mathrm{AD}$ \\
regimes
\end{tabular}} & Type of RTAs & $\begin{array}{ll}\text { Average annual } & \mathrm{AD} \\
\text { initiations by } & \mathrm{US} \\
\text { against partner } & \\
(1995-2013) & \end{array}$ & $\begin{array}{l}\text { Year } \\
\text { of } \\
\text { entry } \\
\text { into } \\
\text { force } \\
\end{array}$ & $\begin{array}{l}\text { Average annual } \\
\text { AD initiations } \\
\text { by US against } \\
\text { partner after the } \\
\text { entry into force }\end{array}$ \\
\hline Jordan & \multicolumn{2}{|l|}{ A } & FTA \&EIA & 0 & 2001 & 0 \\
\hline Oman & \multicolumn{2}{|l|}{$\mathrm{A}$} & FTA \&EIA & 0 & 2009 & 0.2 \\
\hline Peru & \multicolumn{2}{|l|}{$\mathrm{A}$} & FTA \&EIA & 0 & 2009 & 0 \\
\hline Australia & \multicolumn{2}{|l|}{$\mathrm{A}$} & FTA \&EIA & 0.16 & 2005 & 0.11 \\
\hline Israel & $\mathrm{A}$ & & FTA & $0.27 *(1985-2013)$ & 1985 & 0.37 \\
\hline Colombia & $\mathrm{A}$ & & FTA \&EIA & 0.05 & 2012 & 0 \\
\hline $\begin{array}{l}\text { Canada } \\
\text { (NAFTA) }\end{array}$ & $\mathrm{C}$ & & FTA \&EIA & $2.12 *(1979-2013)$ & 1994 & 0.85 \\
\hline $\begin{array}{l}\text { South } \\
\text { Korea }\end{array}$ & $\mathrm{C}$ & & FTA \&EIA & $2.18 *(1992-2013)$ & 2012 & 1.5 \\
\hline $\begin{array}{l}\text { Mexico } \\
\text { (NAFTA) }\end{array}$ & $\mathrm{C}$ & & FTA \&EIA & $1.45 *(1983-2013)$ & 1994 & 1.3 \\
\hline
\end{tabular}

\footnotetext{
${ }^{4}$ According to WTO RTA Database, FTA refers to Free Trade Agreement, and EIA refers to Economic Integration Agreement.
} 


\begin{tabular}{|l|l|l|l|l|l|}
\hline \multicolumn{2}{|l|}{ Examples of India's RTAs } & $\begin{array}{l}\text { Type of } \\
\text { regional AD } \\
\text { regimes }\end{array}$ & $\begin{array}{l}\text { Type of } \\
\text { RTAs }\end{array}$ & $\begin{array}{l}\text { Average annual AD } \\
\text { initiations by India } \\
\text { against partner } \\
(1995-2013)\end{array}$ & $\begin{array}{l}\text { Year of } \\
\text { entry } \\
\text { into } \\
\text { force }\end{array}$ \\
ASEAN & A & FTA & 6.37 & 2010 & $\begin{array}{l}\text { Average annual AD } \\
\text { initiations by India } \\
\text { against partner } \\
\text { after the entry into } \\
\text { force }\end{array}$ \\
\hline Chile & A & PTA & 0 & 2007 & 0 \\
\hline India & A & PTA & 0 & 2003 & 0 \\
\hline Japan & C & $\begin{array}{l}\text { FTA } \\
\text { \&EIA }\end{array}$ & 1.74 & 2011 & 0.33 \\
\hline Malaysia & C & $\begin{array}{l}\text { FTA } \\
\text { \&EIA }\end{array}$ & 1.11 & 2011 & 0.67 \\
\hline Singapore & C & $\begin{array}{l}\text { FTA } \\
\text { \&EIA }\end{array}$ & 1.26 & 2005 & 0.55 \\
\hline South Korea & C & $\begin{array}{l}\text { FTA } \\
\text { \&EIA }\end{array}$ & 2.79 & 2010 & 2.25 \\
\hline
\end{tabular}

Note: For the US's RTAs marked with asterisks, the research period is that in the parenthesis.

Source: Documents of RTAs listed in WTO's RTA database and Bown, Chad P. (2014)

"Global Antidumping Database," The World Bank, June, available

In Table 9, there are a total of 10 RTAs that have modified traditional WTO AD

rules. All the partners in these 10 RTAs had at least once suffered from the AD investigation initiated by EU, US or India before the signature of RTAs. Fortunately, through the restrictive regional $\mathrm{AD}$ regimes, their $\mathrm{AD}$ situation seems to be improved with the declining trend of their annual average $\mathrm{AD}$ initiations following the implementation of RTAs (as in the US's RTAs and India's RTAs) or with no initiation of AD investigation in EU's newly RTAs.

Table 9 also shows that all of these 10 RTAs, altering AD provisions, belong to the type of EIA (economic integration agreement), which is consistent with the prospect of economic development and integration through RTA's partnership.

What can these benefits from economic development and integration be? In Table 10, we list some examples. These examples suggest that by offering open market 
access in trade, services and in investment, a significant tariff reduction schedule and other broader cooperation covering competition, government procurement, intellectual property rights, and transparency, South Korea, Canada and Malaysia ameliorated AD impacts in their RTAs' partnership.

Table10 Examples of the economic inducement used in RTAs altering AD use

\begin{tabular}{|l|l|}
\hline Names of RTAs & Prospect of economic development \\
\hline EU-South Korea & $\begin{array}{l}\text { First completed agreement with the full coverage in goods and services } \\
\text { in a new generation of FTA launched by the EU in } 2007 .\end{array}$ \\
& $\begin{array}{l}\text { Only a limited number of agricultural products are excluded from tariff } \\
\text { elimination. } \\
\text { and Improved market access conditions on legal, financial, transportation } \\
\text { financial institutions to provide and transfer financial information and data } \\
\text { across their borders and provide advisory services. } \\
\text { - Broad cooperation in competition, government procurement, } \\
\text { intellectual property rights, transparency in regulation to sustainable } \\
\text { development, all of which are firstly addressed in the EU's RTA with Asian } \\
\text { economy. }\end{array}$ \\
\hline Canada-US & $\begin{array}{l}\text { Implicit side payments in the form of domestic policy disciplines favorable } \\
\text { to United States, including changes in energy and investment policies and } \\
\text { also changes in pharmaceutical protection laws. }\end{array}$ \\
\hline South Korea-US & $\begin{array}{l}\text { Providing new market access and level the playing field for U.S. auto } \\
\text { manufacturers and workers. } \\
\text { E Extensive topics covered including intellectual property, government } \\
\text { procurement, security and also the competition. } \\
\text { - Korea provides meaningful market access commitment in services like } \\
\text { financial services, eg, US financial service providers are allowed to provide } \\
\text { through commercial presence all existing financial services and any new } \\
\text { ones in South Korea. } \\
- \text { Large scale of tariff reduction and tariff-rate quotas on a broad range of } \\
\text { products even including agriculture products. }\end{array}$ \\
$\begin{array}{l}\text { Broad and length coverage including investment, intellectual property and } \\
\text { service access, which contributes to more prospective of their economic } \\
\text { integration and development through such bilateral RTAs relationships. }\end{array}$ \\
\hline
\end{tabular}

Source: Official documents published by the office of the United States Trade representatives; Official documents of the European Commission; Whalley, J. (1996), 'Why do countries seek regional trade agreements?'; Legal text of all the RTAs agreements

Table 11 lists detailed AD altering provisions in the representatives RTAs. First, 
there are rules that affect the likelihood of imposing AD duties. South Korea-US and India-Malaysia RTAs prohibit zeroing in their regional AD provisions. Zeroing is a method of calculating dumping margins, in which negative individual dumping margin is counted as zero and only positive individual margins shall be counted while calculating dumping margin. This method will easily lead to a higher margin of dumping in determination than de minimis margin of $2 \%$, a threshold of the determination of dumping margin in article 5.8 of WTO AD rules. RTA provisions that prohibit zeroing could lower the margin of dumping, and thus, an $\mathrm{AD}$ investigation against RTA members will become more possible to be terminated. Moreover, in EU-South Korea and South Korea-US RTAs, one article specifies that for any $\mathrm{AD}$ measures on goods originating in the other party that have been terminated in the previous 12 months as a result of a review, the investigation shall not proceed, unless this preinitiation examination of the application for the $\mathrm{AD}$ initiation indicates that the circumstances have changed. This provision could thus reduce the likelihood of $\mathrm{AD}$ initiation.

Second, there are rules that decrease the AD duties level. This is often referred to as a lesser duty rule. In WTO AD rules, it is desirable that the AD duty be less than the margin if such lesser duty would be adequate to remove the injury to the domestic industry, which suggests that a lesser duty rule is only encouraged. However, India-Malaysia and South Korea-US RTAs mandate the lesser duty rule in the application of an AD duty. Such a mandate in a RTA can provide a significant advantage to members, because in the event that an $\mathrm{AD}$ action is taken against RTA's 
partners and non-partners, a lower AD duty will be imposed on the RTA partners even though the $\mathrm{AD}$ investigation might have found the same dumping margin against all suppliers (see as Prusa (2014)).

Thirdly, there are rules that enhance cooperation and transparency in the application of $\mathrm{AD}$ actions, all of which will mitigate the administrative discretion at the intra-RTA level. The best known example is the creation of regional review bodies in Chapter 19 of NAFTA, which allows a binational panel to review the final AD determination made by the authority of another NAFTA partner (Prusa 2014). Moreover, EU-South Korea and South Korea-US RTAs also improve cooperation with provisions of setting up working groups on trade remedy cooperation, and India-Malaysia RTA specifies article 5.12 related to the issue of cooperation. In addition, in order to limit administrative discretion in the procedure of review resulting from the vagueness of the threshold in the determination of dumping and injury, EU-South Korea and South Korea-US RTAs mandate the application of de-minimis threshold set out in Article 5.8 of WTO AD rules in the procedure of review.

Table 11 Example of modified AD provisions in RTAs

\begin{tabular}{|l|ll|}
\hline Names of RTAs & \multicolumn{2}{|l|}{ Altering points in regional AD regimes } \\
\hline EU-South Korea & $\bullet$ & De-minimis standard applicable to review \\
& $\bullet$ & Exemption investigation after termination resulting from a review \\
& $\bullet$ & Lesser duty rule as mandatory rule \\
& $\bullet$ & Setting up a working group on trade remedy cooperation \\
\hline Canada-US, & Introduction of regional review bodies \\
NAFTA & \multicolumn{1}{|c|}{} \\
\hline South Korea-US & $\bullet$ & De-minimis standard applicable to review \\
& - & Exemption from investigation after termination \\
& $\bullet$ & Prohibition of zero \\
& $\bullet$ & Setting up a working group on trade remedy cooperation \\
\hline
\end{tabular}




\begin{tabular}{|l|ll|}
\hline India-Malaysia & $\bullet$ & Less-duty rules as mandatory rule \\
& $\bullet$ & Prohibition of zero \\
& $\bullet$ & Exemption from investigation after termination \\
& $\bullet$ & Cooperation \\
\hline
\end{tabular}

Source: Legal text of RTAs agreements in the WTO's RTAs data source

\section{d. The effects of existing RTAs on mitigating China's AD problems}

By October/2014, China had 19 RTAs at various stages of execution, among which 15 agreements have been signed already. With the exception of China-Hong Kong and China-Macau RTAs ${ }^{5}$, China has not yet made any substantial modifications in regional $\mathrm{AD}$ regimes, though there are some alterations, regarding information contact points or general mention of cooperation and notification, in China-Peru, China-Costa Rica, China-New Zealand and China-Singapore RTAs. In this subsection, we analyze the changing pattern of AD actions against China by 7 RTA partners ${ }^{6}$ following the implementation of RTAs.

Have these RTAs decreased China's AD threat from its partners? Chinese research papers addressing this issue have found that RTAs have increased rather than decreased AD appeal actions brought by RTAs' members against China (see Yan Zhang and Jianguo Xie (2011) and Yanhua He (2012)). However, since these studies focus only on the number of $\mathrm{AD}$ investigations by RTAs' contracting members, this research fails to consider the role of the large share of imports from China resulting from intra-RTA trade creation effects in the rising AD appeal actions. We use the AD

\footnotetext{
${ }^{5}$ The AD use is eliminated in these two domestic RTAs.

${ }^{6}$ We exclude Australia, China Hong kong, Macao, Chinese Taibei, Switzerland, Iceland, Singapore, Philippines, Costa Rica, Chile, and the other members in ASEAN and APTA. The reasons are as follows. Firstly, in November2014, China practically concluded Free Trade Agreement Negotiations with Australia, while the full texts of these RTAs are not available to the public yet. Secondly, because of inadequate AD data resulting from its 3-years long history of RTA with China, we exclude Peru. Thirdly, 4 countries (Switzerland, Iceland, Costa Rica and Chile), 7 countries in ASEAN (Singapore, Philippines, Lao, Combodia, Vietnam, Brunei and Myanmars), two countries in APTA (Sri lanka and Bangladesh), China Hong Kong and Macao seldom or even never take AD actions against China. Fourthly, the RTA with Chinese Taibei is only a framework agreement without any regional AD regimes, so it is not the focus of our paper.
} 
measure, AD intensity and ADD to reexamine the effects of RTAs on mitigating the severity of China's AD problems. Because of the difference in the year of entry into force for each RTAs, the year of entry into force of RTAs is defined as t, one year prior to the entry into force is set as $t-1$, two years before the entry into force is set as $t-2$, three years before the entry into force of RTAs is set as $t-3$, one year after the entry into force of RTAs is set as $t+1$, two years after is set as $t+2$,and so on. Table12 indicates the changing pattern of AD measures taken by China's RTAs partners before and after the entry into force of RTAs.

Table12 Pattern of AD measures against China with the formation of RTAs

\begin{tabular}{|c|c|c|c|c|c|c|c|}
\hline Time & India & Korea & Malaysia & Thailand & Indonesia & $\begin{array}{l}\text { New } \\
\text { Zealand }\end{array}$ & Pakistan \\
\hline$t-3$ & 5 & 1 & 1 & 0 & 1 & 0 & 0 \\
\hline $\mathrm{t}-2$ & 8 & 0 & 0 & 1 & 1 & 1 & 1 \\
\hline $\mathrm{t}-1$ & 12 & 0 & 0 & 0 & 1 & 1 & 1 \\
\hline $\mathrm{t}$ & 12 & 1 & 0 & 0 & 0 & 0 & 0 \\
\hline$t+1$ & 5 & 2 & 0 & 1 & 0 & 0 & 1 \\
\hline $\mathrm{t}+2$ & 5 & 1 & 0 & 1 & 1 & 1 & 3 \\
\hline$t+3$ & 10 & 1 & 0 & 1 & 0 & 0 & 1 \\
\hline $\mathrm{t}+4$ & 8 & 1 & 0 & 1 & 2 & 0 & 1 \\
\hline$t+5$ & 9 & 5 & 0 & 1 & 1 & 0 & 0 \\
\hline$t+6$ & 12 & 1 & 0 & 4 & 2 & $*$ & 0 \\
\hline $\mathrm{t}+7$ & 9 & 0 & 2 & 1 & 0 & $*$ & $*$ \\
\hline $\mathrm{t}+8$ & 8 & 0 & 1 & 0 & 0 & $*$ & $*$ \\
\hline $\begin{array}{l}\text { Name of } \\
\text { RTA with } \\
\text { China }\end{array}$ & APTA & APTA & ASEAN & ASEAN & ASEAN & $\begin{array}{l}\text { China-New } \\
\text { Zealand } \\
\text { RTA }\end{array}$ & $\begin{array}{l}\text { China- } \\
\text { Pakistan } \\
\text { RTA }\end{array}$ \\
\hline $\begin{array}{l}\text { Date of } \\
\text { entry into } \\
\text { force }\end{array}$ & $\begin{array}{c}01 / 01 / \\
2002\end{array}$ & $\begin{array}{c}01 / 01 / \\
2002\end{array}$ & $\begin{array}{c}01 / 01 / \\
2005\end{array}$ & $\begin{array}{c}01 / 01 / \\
2005\end{array}$ & $\begin{array}{c}01 / 01 / \\
2005\end{array}$ & $01 / 10 / 2008$ & $\begin{array}{c}10 / 10 / \\
2009\end{array}$ \\
\hline $\begin{array}{l}\text { Type of } \\
\text { regional } \\
\mathrm{AD} \\
\text { regime }\end{array}$ & A & A & A & A & A & $\begin{array}{c}\text { A+ notify } \\
\text { the contact } \\
\text { point }\end{array}$ & A \\
\hline
\end{tabular}

Note: Since the RTA with New Zealand has been implemented since 2008, there are no data since $\mathrm{t}+6$. And the same reason for Pakistan, because the year of entry into force of its RTA with China is 2007 . 
Source: Calculation based on Bown, Chad P. (2014) "Global Antidumping Database," The World Bank, June, available; Documents of RTAs listed in WTO's RTA database

As shown in Table 12, among the 7 countries except New Zealand, simply confirming the WTO's AD agreements without any modification in ASEAN-China, APTA and China-Pakistan RTA, there seems no declining tendency of AD measures taken against China. By contrast, New Zealand, with some enhancement of transparency in the regional $\mathrm{AD}$ regimes with China, has seldom taken $\mathrm{AD}$ measures against China since the implementation of RTAs, which suggests the importance of enhanced transparency in mitigating regional AD problems.

Table13 Changing pattern of Annual AD intensity index with implementation of RTAs

\begin{tabular}{|l|r|r|r|r|r|r|}
\hline & \multicolumn{1}{|l|}{ India } & \multicolumn{1}{l|}{ Korea } & \multicolumn{1}{l|}{ Malaysia } & \multicolumn{1}{l|}{ Thailand } & Indonesia & Pakistan \\
\hline $\mathrm{t}-3$ & 3.110 & 1.688 & 2.563 & 0.000 & 2.166 & none \\
\hline $\mathrm{t}-2$ & 5.266 & none & none & 4.167 & 1.069 & 0.822 \\
\hline $\mathrm{t}-1$ & 3.177 & none & none & 0.000 & 2.226 & 2.558 \\
\hline $\mathrm{t}$ & 2.593 & 0.874 & none & none & none & none \\
\hline $\mathrm{t}+1$ & 1.893 & 0.907 & none & 3.148 & none & 2.978 \\
\hline $\mathrm{t}+2$ & 3.106 & 2.529 & none & 4.233 & 0.831 & 0.964 \\
\hline $\mathrm{t}+3$ & 4.337 & 1.690 & none & 8.910 & 0.000 & 0.650 \\
\hline $\mathrm{t}+4$ & 2.778 & 0.910 & none & 7.855 & 1.994 & 0.962 \\
\hline $\mathrm{t}+5$ & 1.836 & 1.887 & none & 3.762 & 2.194 & \\
\hline $\mathrm{t}+6$ & 2.064 & 1.132 & none & 2.299 & 2.172 & \\
\hline $\mathrm{t}+7$ & 2.378 & none & 1.200 & 1.340 & none & \\
\hline $\mathrm{t}+8$ & 1.596 & none & 0.763 & none & none & \\
\hline
\end{tabular}

Source: Calculation based on Bown, Chad P. (2014) "Global Antidumping Database," The World Bank, June, available and International Trade Indicators in UNCTAD Statistics

We have also calculated an annual AD intensity index based on the method used by Chu and Prusa (2004) ${ }^{7}$. The calculation method is as follows:

the proportion of number of AD measures against China $\mathrm{AD}$ intensity index $=\frac{\text { by the total number of AD initiations against World in one year }}{\text { the share of Chinese's products in initiator country's }}$ import markets in one year

\footnotetext{
${ }^{7}$ In the paper by Chu and Prusa (2004), the denominator in this intensity measure is China's share in world imports, and this measures the overall possibility of an economy's exports being subject to AD duties. Since we discuss the possibility being subject to AD duties by each RTA members with the implementation of RTAs, we make some alteration in calculation by setting the share of Chinese's products in RTA member's import markets.
} 
As shown in Table 13, even after the implementation of RTAs, AD intensity indices in 4 out of 6 countries with regional AD regimes of Category A are usually above 1, which means that their AD measures against China are disproportionately severe compared with the increased share of China's import resulting from the trade creation effects of RTAs. Such a high level of AD intensity after the implementation of RTAs may be due to the fact that these RTAs simply confirm WTO AD rules.

In Table 14, we make comparisons of country ADD levels worldwide and against China between pre and post the implementation of RTAs. The 6 countries with the exception to India in Table 14 have acknowledged China's market economy status since 2004.We find that ADD levels imposed on China's export by the 5 countries have become higher than their ADD levels worldwide since the implementation of RTAs, and the only exception is Malaysia. And also the average annual AD initiations against China after the implementation of RTAs are larger than those prior to the implementation in all the 6 countries. These data underscores the argument that as China fails to take the initiative of modifying regional AD regimes in its RTAs, there seems only a weak effect of regional AD provisions in mitigating China's AD problems.

Table 14 AD actions against China and implementation of RTAs

\begin{tabular}{|c|c|r|r|r|r|}
\hline \multirow{2}{*}{ Country } & \multirow{2}{*}{ Period } & \multicolumn{3}{|c|}{ AD duty } & $\begin{array}{c}\text { Average annual } \\
\text { AD initiations } \\
\text { against China }\end{array}$ \\
\cline { 3 - 7 } & Against World & Against China & China/world & 6.43 \\
\hline \multirow{3}{*}{ India } & $1995-2001$ & $101.16 \%$ & $121.94 \%$ & 1.21 & 9.33 \\
\cline { 2 - 6 } & Since 2002 & $80.93 \%$ & $128.40 \%$ & 1.59 & 1 \\
\hline \multirow{2}{*}{ Korea } & $1995-2001$ & $33.38 \%$ & $33.30 \%$ & 0.997 & 1.58 \\
\cline { 2 - 6 } & Since 2002 & $16.82 \%$ & $18.32 \%$ & 1.09 & \\
\hline
\end{tabular}




\begin{tabular}{|c|l|r|r|r|r|}
\hline Malaysia & $1995-2004$ & $47.95 \%$ & $186 \%$ & 3.88 & 0.1 \\
\cline { 2 - 6 } & Since 2005 & $19.70 \%$ & $15.78 \%$ & 0.80 & 0.44 \\
\hline \multirow{3}{*}{ Thailand } & $1995-2004$ & $44.03 \%$ & $32.96 \%$ & 0.75 & 0.2 \\
\cline { 2 - 6 } & Since 2005 & $39.91 \%$ & $42.50 \%$ & 1.06 & 1.67 \\
\hline \multirow{2}{*}{ Indonesia } & $1995-2004$ & $31.83 \%$ & $22.02 \%$ & 0.77 & 0.5 \\
\cline { 2 - 6 } & Since 2005 & $29.87 \%$ & $34.57 \%$ & 1.16 & 0.67 \\
\hline \multirow{2}{*}{ Pakistan } & $1995-2009$ & $20.29 \%$ & $13.96 \%$ & 0.69 & 0.4 \\
\cline { 2 - 6 } & Since 2009 & $26.21 \%$ & $34.48 \%$ & 1.32 & 1.25 \\
\hline
\end{tabular}

Source: Calculation based on Bown, Chad P. (2014) "Global Antidumping Database," The World Bank, June, available

\section{Implications for China's RTA Bargaining Strategy Addressing Mitigating AD Problems}

On the basis of the discussion above, we suggest that China should take the initiative to mitigate $\mathrm{AD}$ problems by using regional or bilateral negotiations, especially as there exists higher concentration in the composition of $\mathrm{AD}$ initiators as we discussed above. However, among the top 8 initiators of $\mathrm{AD}$ activities against China, China has only recently concluded substantive negotiations on a bilateral free trade agreement with Australia in Nov/2014. Because some Chinese scholars found that the more RTAs one country implemented from which China is excluded, the higher incidences of $\mathrm{AD}$ cases against China this country will initiate (see as Xiaosong Wang, 2009), it is believed that the "protection diversion" effects of RTAs (see as Bhagwati, 1993; Bown, 2007) exist in RTAs with China's AD initiators as parties. Therefore, if China has been excluded from the RTAs with the top initiators as parties to them, China's AD problems will further intensify. China could thus take the initiative to establish RTAs with its major AD initiators.

Our earlier analysis on the role of RTAs in lessening AD problems emphasizes the concessions that might be expected to pay as a price from one partner for addressing the amelioration of $\mathrm{AD}$ matters. Consequently, China should make 
concessions and put forward an attractive bid package in exchange for better AD treatment. In relieving AD problems, China should first attempt to obtain the market economy status, accorded by intensive AD countries including India, US and EU, through regional or bilateral negotiation. Though China's non-market economy status agreed to in its WTO accession negotiation is set to expire in 2015, other possibilities exist for proposals in RTA negotiation, since we found that there seems only a weak effect of current regional $\mathrm{AD}$ provisions in mitigating China's $\mathrm{AD}$ situations. Therefore, in the long run, China could, by the establishment of new RTAs with intensive AD users such as U.S., EU, India, Argentina and Brazil, or upgrading of existing RTAs, offer attractive terms to exchange for AD provisions with higher transparency and low discretion in RTA negotiation.

When it comes to negotiation with developed countries, U.S. and EU, which rank among the top 3 of AD initiators against China, need to receive considerable attention. China has a strong interest in using negotiation with the U.S. and EU to improve AD matters. Modification in the regional AD provisions could be de-minimis standard applicable to review, lesser duty rule as a mandate, the prohibition of zeroing and setting up a Working Group on Trade Remedy Cooperation (as in the EU-South Korea and South Korea-US RTA).

Though currently excluded from TPP or TTIP negotiations, China might also partially mitigate its AD problems by negotiation in China-U.S. bilateral investment treaties (referred to as BIT) that has already finished the $14^{\text {th }}$ round or Sino-EU BIT that has completed the 3 th round. Since the increasing economic and political 
popularity of $\mathrm{AD}$ against China taken by US and EU stem from their weakened economic growth, trade deficits from China and China's inadequate demand of their products (Davis, 2009), a BIT could serve as one way to lessen China's AD actions taken by EU and US, by significantly increasing reciprocal flows of FDI in both parties, and 'level the playing field' for U.S. and EU companies with the opening of many Chinese sectors. For example, Daniel C.K. Chow (2014) argues that a BIT will allow China to evade or mitigate the effects of border measures imposed by the United States on imported goods from China.

But to make gains in ameliorating traditional AD provisions in future RTA negotiations with US and EU, China may have to make concessions in other areas of interest. These areas might include government procurement, progressive further opening of service industries, and cooperation on environment protection. All these 3 areas are listed among the ambitious agenda in the TPP negotiation led by U.S. and also receive considerable attention in EU-China bilateral economic relations in EU's 2020 strategy published by the European Commission. China could also pay a price in a bid of improvement in the formation mechanism of Renminbi exchange rate on which the U.S. and EU have always exerted strong pressure. The bid package in these areas is consistent with China's economic development mission ${ }^{8}$, which will make such concessions more feasible.

\footnotetext{
${ }^{8}$ According to the 'Decision of the CCCPC on Some Major Issues Concerning Comprehensively Deepening the Reform' published by Central Committee of the Communist Party of China in 01/17/2014', in the task of 'building a new open economic system', China 'will promote the orderly opening up of finance, education, culture, healthcare and other service sectors', and 'will reform the management systems of market access, customs oversight, inspection and quarantine, and others, and accelerate negotiations on environmental protection, investment protection, government procurement, e-commerce and other such new fields, so as to form a global, high-standard network of free trade zones.' In the task of 'Improving the financial market', China 'will improve the mechanism for market-based Renminbi exchange rate formation, and promote the opening of the capital market in both directions.'
} 
With regards to frequent $\mathrm{AD}$ users from developing countries such as India, Argentina and Brazil, their proliferation of AD protection against China's exports stem from the fact that their products with comparative advantage overlap to a large degree with China's comparative advantage products. This results from many similarities between China and other developing countries in terms of factor abundance, country's development path and the position in the global value chain. Therefore, a bid package with the aim of boosting their economic development can play a role in mitigating their $\mathrm{AD}$ actions against China.

At present, China is actively pursuing strategic analysis of an Asia-Pacific free trade zone, as well as being an active participator in the negotiations on upgrading "ASEAN $10+1$ " and RCEP. Considering the weak mitigating effects of AD protection by ASEAN against China due to the regional AD regimes simply referring to WTO AD rules in China-ASEAN RTA, China could address modification in regional $\mathrm{AD}$ regimes by offering attractive bids during the following upgrades negotiations. These attractive bids may be in the area of opening service sectors, because of the limited openness level by China's commitments in the current ASEAN-China RTA (Bo Yuan and Rui Wang, 2014). In addition, China has already launched the construction of 'Silk Road Economic Belt and a Maritime Silk Road 'to enhance connectivity and accessibility.

Similarly, China can also resort to RTA bargaining with India so as to restrict AD use with provisions such as the prohibition of zero, less-duty rules as mandate and cooperation (as in the India-Malaysia RTA), as China and India finalized a report on 
the feasibility of RTA in 2007. India is one of the members in the RCEP. In the RTA negotiation with India, China could also offer, as a bid package, improvements of accessibility and connectivity of the markets in sectors such as railway infrastructure, further opening service sectors and expansion of duty-free good categories. China could also take into consideration the construction of RTAs with major AD initiators in South America such as Argentina, Brazil, Mexico and Colombia.

\section{Concluding Remarks}

We highlight the severity of China's AD problems: the largest target economy in terms of both $\mathrm{AD}$ initiations and $\mathrm{AD}$ measures, high $\mathrm{AD}$ intensity, and very high $\mathrm{AD}$ duty level. We note much higher concentration in the AD actions taken by top 4 and top 8 AD initiators against China than those by top $\mathrm{AD}$ initiators worldwide, while China has only one out of top 8 initiators as RTA's partners. Because of the "protection diversion" of RTAs, We suggest that China could thus take the initiative to establish RTAs with its major AD initiators, in part as a way of offsetting the impacts of such duties.

Current research deals little with how RTAs can succeed in mitigating AD problems at the intra-RTA level. By synthesizing the literature on objectives of AD and that of RTAs, we argue that during RTA negotiations, one party can offer a bid with higher level of economic integration and economic openness in exchange for a kind of improvement in regional AD matters. Among the two regional AD provisions aiming at mitigating $\mathrm{AD}$ protection at the intra-RTA level, we suggest that for China, regional provisions restricting $\mathrm{AD}$ protection are more feasible than those prohibiting 
the AD use.

We differ from studies on PTAs and AD by Prusa (2014) and Zimring (2014) who focus on the case of NAFTA, by making case studies on RTAs involving EU, US and India, and focus on the features of their regional AD provisions, and also their $\mathrm{AD}$ usage patterns prior to and after the implementation of RTAs. Our results support the argument that the impetus of economic integration can alter $\mathrm{AD}$ provisions in their RTAs and also the effect of such alterations can motivate China's regional approach to mitigating $\mathrm{AD}$ problems.

We also discuss the effects of existing RTAs on mitigating China's AD problems. Since any substantial modifications have yet to be made in the regional AD regimes concluded by China with foreign countries, there seems to be a weak role for current RTAs in mitigating China's AD problems. Therefore, China could become more active in mitigating $\mathrm{AD}$ problems by directly seeking alterations in regional $\mathrm{AD}$ provisions.

We conclude by outlining a possible China bargaining strategy to mitigate the AD situation in RTAs. China could first to obtain market economy status, accorded by intensive AD countries including India, the U.S. and EU. At the same time, China could, by the establishment of new RTAs with intensive AD users or upgrading of existing RTAs, offer attractive bids to exchange for AD provisions with higher transparency and low discretion. We set out some examples of bid packages. 


\section{Reference}

Assaf Zimring (2014), "Preferential Trade Agreements and Anti-dumping Duties", http://www-personal.umich.edu/ assafzim/pta_ad_draft2.pdf

Bhagwati, Jagdish (1993), "Regionalism and multilateralism: an overview", in de Melo, Jaime and Arvind Panagariya (eds.) New Dimensions in Regional Integration, pp.22-51, Cambridge: Cambridge University Press.

Blonigen, Bruce A., and Thomas J. Prusa ( 2001), “Anti-dumping”, NBER Working Paper No. 8398

Bo Yuan and Rui Wang (2014), "Some thoughts on China's current promotion of RCEP's negotiation", International trade, 1,pp.53-56

Bown C, (2007), "China's WTO entry: antidumping, safeguards, and dispute settlement”, NBER Working Paper no. 13349. Cambridge, MA: National Bureau of Economic Research

Chang Hwan Choia. (2014), "Determinants for macroeconomic factors of antidumping: A comparative analysis of India and China", The international trade journal, 28,3,229-245

Daniel C.K. Chow (2014), "Why China wants a bilateral investment treaty with the united states”, Boston University International Law Journal, Forthcoming, Ohio State Public Law Working Paper No. 268

Davis, L. (2009), "Ten years of anti-dumping in the EU I: Economic and political targeting”, ECIPE Working Paper 02/2009.

Ryan Farha ( 2013), “A Right Unexercised is a Right Lost?: Abolishing Antidumping in Regional Trade Agreements", Georgetown Journal of International Law, 44, pp. 211-268

Hoekman, Bernard (1998), "Free Trade and Deep Integration: Antidumping and Antitrust in RTAs." World Bank Policy Research Working Paper No. 1950. Washington, D.C.: World Bank

Jean-Daniel Rey (2012), “Antidumping regional regimes and the multilateral trading system: do regional antidumping regimes make a difference?", Working Paper 
ERSD-2012-22 of WTO,http://www.wto.org/english/res_e/reser_e/ersd201222_e.htm

Chunding Li, Jing Wang, John Whalley (2014), “China and Global Mega Trade Deals”. CIGI Papers No.34, July 2014

Mastel, Greg (1998), “Antidumping laws and the U.S. economy”, Armonk, NY: ME Sharpe.

Robert Teh, Thomas J. Prusa, Michele Budetta (2007), “Trade remedy provisions in Regional Trade Agreements", Staff Working Paper ERSD-2007-03, World Trade Organization Economic Research and Statistics Division.

Lifang Song (2012), 'Antidumping frictions against China and China's countermeasures', China's soft science, 2,5-15

Thomas J. Prusa and Susan Skeath (2001), "the economic and strategic motives for antidumping filings”, NBER Working Papers 8424, National Bureau of Economic Research, Inc.

Thomas J. Prusa and Robert Teh (2010), "Protection reduction and diversion: PTAs and the incidence of antidumping disputes", NBER Working Paper 16276.

Thomas J. Prusa, (2005), “Antidumping: a growing problem in international trade",The World Economy,28, pp. 683-700.

Thomas J. Prusa, (2014), “Antidumping provisions in Preferential Trade Agreements",https://www.sais-jhu.edu/sites/default/files/Prusa.pdf (draft online)

Tianshu Chu and Thomas J. Prusa ( 2004), "the reasons for and the impact of antidumping protection: the case of People's Republic of China”, Economics Study Area Working Papers 69, East-West Center, Economics Study Area.

John Whalley (1996), "Why do countries seek regional trade agreements?", NBER WP 5552 (Cambridge MA)

Xiaohua Bao (2011), "Has China suffered from discriminatory anti-dumping treatment",management world, 3,pp.32-43

Xiaosong Wang and Shenxiang Xie (2009), "why China has suffered from anti-dumping: empirical study on cross-national and cross-sectoral data", management word,12, pp.27-38

Yan Zhang and Jianguo Xie (2011), "Does Regional Trade Agreements Decrease 
Members' Antidumping Threat? An Analysis of China Experience", Journal of International Trade,8, pp.122-131

Yanhua He (2012), "Research on the Antidumping Legal System in the RTAs", Ph.d dissertation, East Chinese University of Political Science and law 